\title{
周波数変調型ケルビンプローブ原子間力 顕微鏡による有機薄膜評価
}

\author{
山田啓文 \\ 京都大学工学研究科 傿615-8510 京都府京都市西京区京都大学桂 \\ （2007 年 3 月 28 日受理）
}

\section{Investigations of Organic Materials by Kelvin Probe Force Microscopy using Frequency Modulation Method}

\author{
Hirofumi YAMADA \\ Graduate School of Engineering, Kyoto University \\ Katsura, Nishikyo-ku, Kyoto 615-8510
}

(Received March 28, 2007)

\begin{abstract}
Kelvin probe force microscopy (KFM), which has been a common method for studying electrical properties of nanometer-scale structures, is a dynamic-mode atomic force microscopy (AFM) technique combined with a traditional Kelvin probe method used for measuring macroscopic contact potential differences. It allows us to map electron affinity or work function on a nanometer scale. In this article KFM using a frequency modulation detection method (FM-KFM) is first explained briefly. The frequency modulation method plays an essential role in high-sensitive interaction force detection. We also describe applications of FM-KFM to the nanometer-scale surface potential investigations of organic materials including phase-separated self-assembled monolayer films (PS-SAM films) and single polymer crystal surfaces. Furthermore, recent results on the local surface potential study of carbon nanotube field effect transistors using FM-KFM is presented.
\end{abstract}

KEYWORDS: KFM, FM detection, NC-AFM, contact potential difference, surface potential

1. 序

ケルビンプローブ原子間力顕微鏡（KFM: Kelvin-probe Force Microscopy) は注1)， その名前からもわかるように, 原子間力顕微鏡（AFM: Atomic Force Microscopy）を, 接触電位差を測定する伝統的手法であるケルビンプロー ブ法（KPM: Kelvin Probe Method）へと応用した高空間 分解能の顕微分析法である。「ケルビンプローブ」とい う名前は, KPMが, 熱力学・電磁気学の分野で名高い 19 世紀後半の数理物理学者 Kelvin 卿 (William Thomson) によって発明されたことに由来する11)。KPMは，長い

E-mail: h-yamada@kuee.kyoto-u.ac.jp

注1 ケルビンプローブフォース顕微鏡と呼ばれることも多い。 略語も KFM の他に KPFM や SKPM などとも記述されてお り, 表記の統一はできていない。なお, KPM が走査型の ケルビンプローブ法を指すこともあるので, Force を示す 訳・略語を付加する方が望ましい。
歴史をもつ伝統的手法であるが，接触電位差あるいは仕 事関数を高精度で測定する計測装置として，表面科学研 究においては現在でも広く用いられている。

一方，KFM の方は，AFM 動作を基にして局所表面電 荷を可視化する目的で開発された静電気力顕微鏡より派 生し，零位法により接触電位差測定を行うケルビンプロ ーブ法と組み合わせることで, 定量的な表面電位が測定 可能な手法となった2)。KFM は AFM 動作に基づいてお り, その空間分解能は高く, また定量的評価が可能なこ とから, ナノスケール電気物性評価のための標準測定法 として広まりつつある。特に, 近年の周波数検出型原子 間力顕微鏡（FM-AFM: Frequency Modulation AFM）の進 展により，AFMによる原子・分子分解能での非破壊観 察が定着しつつあり ${ }^{3)}$ ，KFMによる局所表面電位計測 は，ますます高感度・高分解能化することが期待されて (いる, 5)。 
本稿では，周波数検出型 KFM について概説するとと もに, この手法による有機分子試料の高分解能電位計測, および単層カーボンナノチューブ電界効果トランジスタ の電気特性評価に関する最近の研究について紹介した い。

\section{2. 周波数検出型ケルビンプローブ原子間力 顕微鏡}

\section{1 周波数検出法}

AFM において一般に広く使用されているタッピング モード（間欠接触モード, IC-AFM: Intermittent contact mode AFM） では，カンチレバーを共振周波数（あるい はその近傍）で振動させ，探針が試料に間欠的に接触す ることによって生じる振動振幅の変化を用いて, 試料形 状を測定している6)。しかしながら，真空中など，振動 の $\mathrm{Q}$ 值が高くなる環境では, 振幅変化の測定時間が $\mathrm{Q}$ に反比例して長くなるために, タッピングモードは実用 的ではない。周波数検出型の AFM は, 真空中での測定 時間の応答を改善するために開発された ${ }^{7)}$ 。FM-AFM は, その動作領域が, 通常, 探針と試料が接触しない非 接触領域であることから，しばしば非接触 AFM（NCAFM: Noncontact mode AFM）とも呼ばれる。

間欠接触モードでは, カンチレバーをその自由共振周 波数付近の周波数で強制励振するが, FM-AFM では,

Fig. 1 (a) に示すように, カンチレバーを機械的共振器 とする電気一機械発振系を構成することで, カンチレバ 一は常に共振周波数で振動（自励発振）するようになっ ている。分子間力や静電気力など探針-試料間にはたら く相互作用力はカンチレバーの共振周波数を変化させる ため (Fig. 1（b）参照)，この発振周波数も変化する。 カンチレバーの自由共振周波数, ばね定数, 振動振幅を,
各々 $f_{0}, k, A$ とし, 探針一試料間相互作用力を $F_{t s}(z)$ と すると, この周波数変化 $\Delta f$ は次式で表される8)。

$$
\Delta f=\frac{f_{0}^{2}}{k A} \int_{0}^{1 / f_{0}} F_{t s}(z) \cos \omega_{0} t d t
$$

ただし， $\omega_{0} \equiv 2 \pi f_{0}$ である。通常の FM-AFM では，探針試料間相互作用力が引力領域 $\left(F_{t s}<0\right.$ ：いわゆる “非接 触領域”）で動作するため, $\Delta f$ は負となる注2。

理想的な探針-試料間相互作用は振動周波数の変化だ けをもたらし注3, 振動振幅を変えないが, 現実には, 探 針の力学的振動エネルギーは, 種々の探針一試料間相互 作用を通じて試料側へと移動（散逸）し注4，振動振幅は 減衰する。単位時間当たりの振動散逸エネルギー $\Delta P$ は,

$$
\Delta P=A \omega_{0} \int_{0}^{1 / f_{0}} F_{t s}(z) \sin \omega_{0} t d t=\frac{1}{2} k A^{2} \frac{\omega_{0}}{\mathrm{Q}}\left(\frac{\Delta A}{A}\right)
$$

と表される。ここで, $Q$ は振動の $\mathrm{Q}$ 值， $\Delta A$ は振動散 逸に伴う振幅の変化を表わす。 $\Delta A$ を測定することによ り，試料の各点の $\Delta P$ をマッピングすることが可能と なる（Fig. 1（a）参照。エネルギー散逸像）。

FM-AFM では，上記 $\Delta f$ を検出することで探針-試料

注2 もちろん $\Delta f$ が正でも FM-AFM 動作は可能。この場合, 接触/非接触動作であるかどうかは動作条件に大きく依存 する。

注3 $F t s(z)$ が陽に時間に依存しない場合, 試料への散逸は生ぜ ず， $F_{t s}(z)$ は「保存力」と呼ばれる。もちろんこの場合で も，Q 值で決まるカンチレバー自身のエネルギー損失は 存在する。

注4 エネルギー散逸を引き起こす主な原因としては，振動運 動に伴う探針/試料表面電荷の変動がもたらす変位電流に よって生じるジュール熱損失，試料結晶格子/分子の準安 定的状態へのヒステリシス的な変形（ヒステリシスカ） などがある。接触電位差が存在すると, 前者の理由によ りエネルギー散逸が生じる。

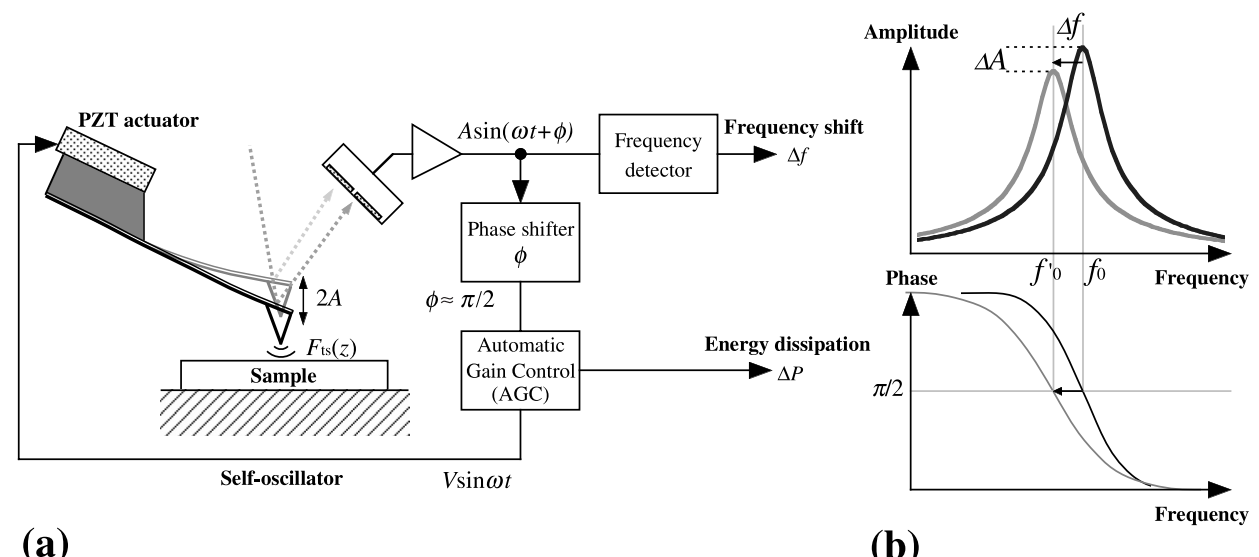

(a)

(b)

Fig. 1. (a) Schematic diagram of frequency modulation atomic force microscopy. (b) Change in cantilever resonance curves caused by tip-sample interactions. Top: amplitude curves. Bottom: phase curves. 


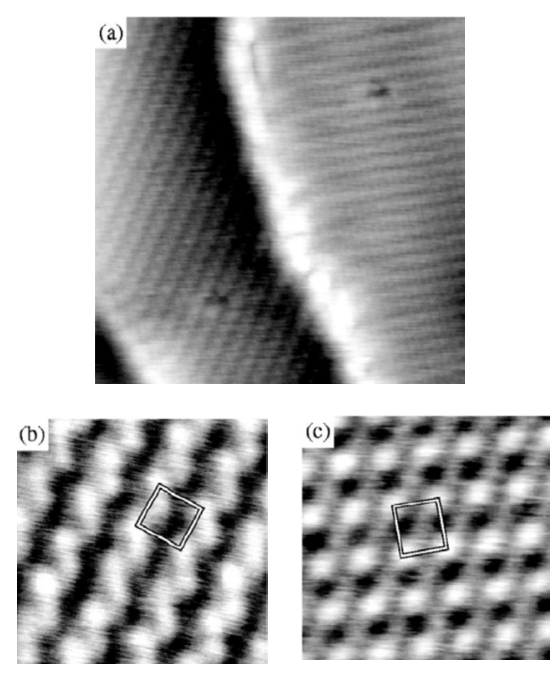

Fig. 2. (a) NC-AFM image of $\mathrm{C}_{12} \mathrm{SAM}$ films on $\mathrm{Au}(111)$ terraces $(20 \mathrm{~nm} \times 20 \mathrm{~nm}, \Delta f=-70 \mathrm{~Hz}, A=5 \mathrm{~nm})$. (b) NC-AFM image of the zigzag-phase structure obtained on the lower terrace shown in (a) $(4.5 \mathrm{~nm} \times$ $4.5 \mathrm{~nm}, \Delta f=-70 \mathrm{~Hz}, A=5 \mathrm{~nm}$ ). (c) NC-AFM image of the rectangular-phase structure taken on the upper terrace $(4.5 \mathrm{~nm} \times 4.5 \mathrm{~nm}, \Delta f=-50 \mathrm{~Hz}, A=5$ $\mathrm{nm})$. Each white square in (b) and (c) indicates the unit cell of each structure. Note that negative frequency shift corresponds to decrease in the resonance frequency (See text explanation).

間にはたらく力を精密に制御する, FM 検出法が用いら れる7)。一方，タッピングモードは，探針-試料間の変 位制御に振動振幅の変化を用いることから, FM-AFM と対比する意味で, AM 検出型 AFM, AM-AFM (Amplitude Modulation AFM）と呼ばれる99。

周波数シフトを検出するにはさまざまな方法がある が，現在もっとも一般的な方法は，位相同期ループ回路 (PLL: Phase-locked Loop）による周波数変化検出法であ $3^{10)}$ 。この方法では電圧制御発振器の出力信号を常に入 力信号に位相同期させ，そのときの電圧制御值を周波数 変化に比例する制御信号として用いる。PLL の特性に もよるが, 回路パラメータの変更を伴わず許容入力周波 数帯域を広く取れること, 高い周波数分解能をもつこと などの特徵から, 現在の FM 検出法では広く用いられて いる。なお, FM-AFMにおける自励発振系内には, 常 にカンチレバーの振幅を一定とするように動作する自動 利得制御（AGC: Automatic Gain Control）回路がしばし ば用いられる (Fig. 1 (a) 参照)。この場合, 上述した 振動散逸による振幅の減衰は, 振幅変化を補償するよう にはたらく利得の変化として捉えられる (零位法)。

FM 検出法のような一見複雑な力検出方法を採用した のは, 既に述べたように, 元々は $\mathrm{Q}$ 值の高い環境にお ける時間応答性の改善がその動機であった。しかしなが
ら，本質的に重要なことは，FM 検出における周波数変 化 $(\Delta f)$ の極性（発振周波数の減少・増加）が探針-試 料間の力の極性(引力・斥力)に対応することから, AFM 動作範囲を探針と試料が接触する直前の微弱な相互作用 領域に設定することが容易となり, 安定な高分解能 NCAFM 動作を可能にしたことである。

Fig. 2 に $\mathrm{Au}$ (111) 基板上に形成されたアルカンチオ 一ル自己組織化単分子 (SAM: Self-assembled monolayers) 膜の FM-AFM（NC-AFM）像（超高真空中）を示す11)。 測定には, 制御系を改造した市販の超高真空 AFM 装置 （日本電子製 JSPM-4500）および FM 検出器として KI2001 XEL（京都インスッルメンツ製）を用いた（カー ボンナノチューブ以外の本稿の実験は, 全て同様の装置 構成)。

アルカンチオール SAM 膜は, $\mathrm{Au}(111)$ 面上で, $\sqrt{3} \times$ $\sqrt{3} \mathrm{R} 30^{\circ}$ 構造や $\mathrm{c}(4 \times 2)$ 構造などのいくつかの異なる 表面構造を示すが, $c(4 \times 2)$ 構造は, 異なる分子面をも つ分子の配置の違いにより, さらにいくつかの表面構造 相をもつ。Fig. 2 (a) の NC-AFM 像では, 基板である 金のステップを境界として，上側テラスに長方相 $(\beta$ 相) が，下側テラスにジグザグ相 $(\delta$ 相）が形成されている ことが確認できる。各々の拡大像を Fig. 2 (b)，(c) に 示す。

タッピングモードにおいて通常用いられている振動振 幅の変化を検出する方法（AM 検出法）では, 振幅変化 は探針-試料間距離に対して単調に変化するため, 引力・ 斥力領域の区別，したがって接触直前の状態の実現が容 易でなく, 瞬間的に完全に接触状態となる間欠接触モ一 ドとして動作することになる12)。

\subsection{KFM の動作原理}

KFM は, 当然ながら KPM 動作に類似しているが, KPM が接触電位差の検出に, 容量結合している探針-試 料間に流れる変位電流を用いるのに対して, KFM では, 探針試料間の静電気力を利用する点が異なっている。 ここでは，その動作原理について簡単に触れておこう。 先ず，探針と試料は，その仕事関数が $\phi_{1}, \phi_{2}$ の金属導 体とする。導体電位を固定しない状態で両導体の真空準 位 $E_{\mathrm{vac}}$ は等しいと仮定すれば，両者のフェルミ準位 $E_{\mathrm{F} 1}$, $E_{\mathrm{F} 2}$ は Fig. 3 のような関係にある。両導体間を電気的に 短絡してフェルミ準位を等しくすると, 導体間には仕事 関数の差 $\Delta \phi$ に相当する接触電位差 $V_{S}(=\Delta \phi / e)$ が生じ, 導体間には電場 $E_{\mathrm{gap}}$ が発生する。この電場の直接の源 は, 探針および試料導体上に誘起された表面電荷であり, 探針-試料微小間隙には電気 2 重層が形成される。試料 表面上に双極子をもつ分子があればこの双極子による分 極からの寄与が上記電気 2 重層に加わる。 

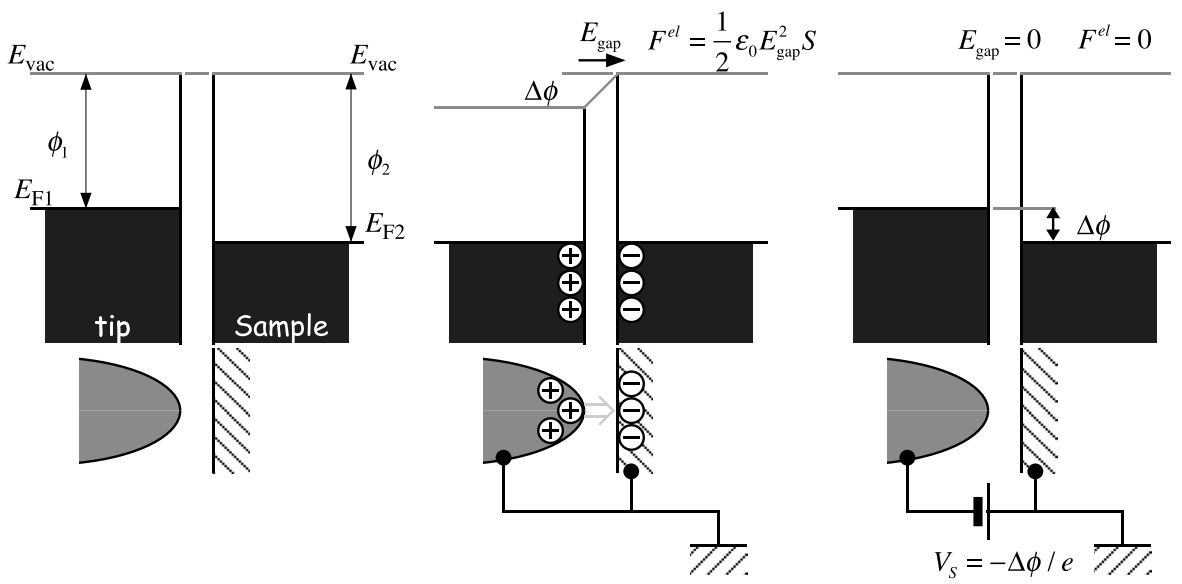

Fig. 3. Energy diagrams of an AFM tip and a sample. They are electrically isolated (left). Both are grounded (center). Both vacuum levels are equalized by an external bias voltage (right). $E_{\mathrm{vac}}$ : vacuum level, $\phi_{1}\left(\phi_{2}\right)$ : tip (sample) work function, $E_{\mathrm{F} 1}\left(E_{\mathrm{F} 2}\right)$ : Fermi energy of the KFM tip (sample).

この状態で, 角周波数 $\omega_{m}$ の交流電圧 $V_{A C}$ を探針-試 料間に加えると, この接触電位差による誘起表面電荷と 交流電場の間にはたらく静電気力により, カンチレバー 自由端上の探針は角周波数 $\omega_{m}$ で振動することになる。 探針一試料間の電気容量を $C$ (ただし, $C$ は探針一試料間 距離 $z$ の関数）とすると, 探針-試料間の静電エネルギ 一 $U^{e l}$ は $C V^{2} / 2$ で与えられるところから, 探針-試料間 にはたらく静電気力 $F_{z}^{e l}$ は, $F^{e l}=-\partial U^{e l} / \partial z$ を考慮して,

$$
\begin{aligned}
F_{z}^{e l}= & -\frac{1}{2} \frac{\partial C}{\partial z}\left(V_{S}+V_{D C}+V_{A C} \cos \omega_{m} t\right)^{2} \\
= & -\frac{1}{2} \frac{\partial C}{\partial z}\left\{\left(V_{S}+V_{D C}\right)^{2}+2\left(V_{S}+V_{D C}\right) V_{A C} \cos \omega_{m} t+\right. \\
& \left.V_{A C}^{2} \cos ^{2} \omega_{m} t\right\}
\end{aligned}
$$

となる。ここで, $V_{D C}$ は外部より加えられた電圧である。 現実の $\partial C / \partial z$ を求めることは容易でないが, 探針を半 径 $R$ の球とする以下の近似式が用いられることが多 ()$^{13)}$ 。

$$
\frac{\partial \mathrm{C}}{\partial \mathrm{z}}=\frac{2 \pi \varepsilon_{0} R}{z}
$$

ただし， $\varepsilon_{0}$ は真空の誘電率を表す。静電気力は電位の 2 乗に比例するため, 応答周波数には DC 成分, $\omega_{m}$ 成分, $2 \omega_{m}$ 成分が含まれる。DC 成分は探針一試料コンデンサ 一電極間に生じる静的な引力, $\omega_{m}$ 成分は上述した直流 電位差により生じた表面誘起電荷が変調交流電場によっ て受ける力, $2 \omega_{m}$ 成分は交流電圧による容量的な力を 反映する。探針に接触電位差を打ち消すように直流電圧 $V_{D C}$ を加えると $\left(V_{S}+V_{D C}=0\right)$, 探針-試料導体は同電位 になり表面電荷は誘起されないために, 上述した角周波 数 $\omega_{m}$ の探針振動は起こらない。したがって，探針・試 料導体に変調電圧 $V_{A C}$ を加えた状態で $\left(V_{D C}=-V_{S}\right)$, 探 針-試料間の静電気力の $\omega_{m}$ 振動応答を抑圧するように
外部電圧を制御することで, 探針電位を基準とする表面 電位あるいは接触電位差（CPD）を求めることが可能と なる。探針には $\mathrm{Au}$ や $\mathrm{Pt}$ など安定な金属を堆積した力 ンチレバーが用いられることが多い。

\section{3 静電気力の検出方式}

KFM では, 探針一試料間距離を制御する AFM 動作が ベース（主帰還制御動作）となって，前述した変調され た静電気力を検出することになる。探針-試料間距離を FM 検出法によって制御する場合においても, 静電気力 検出に FM 検出法を用いるか, あるいは AM 検出法を 用いるかの選択肢が存在する。どちらの場合においても, FM-AFM における静電気力検出では, 静電気力検出の 高感度化のために電場変調周波数としてカンチレバーの 共振周波数を選ぶのが一般的である。

静電気力の $\mathrm{AM}$ 検出においては, 静電気力の変調周 波数として, 低周波の非共振周波数で振動する電圧を探 針一試料間に加え, この静電気力応答を検出するという 方法が用いられる。このとき最小検出電圧は, 検出器雑 音密度を $n_{d e t}, B$ を測定帯域として,

$$
\Delta V_{\min -\mathrm{AM}}=\frac{k A^{1 / 2} d^{1 / 2}}{\sqrt{2} \pi \varepsilon_{0} R f_{0} V_{\mathrm{AC}}} n_{\operatorname{det}} B^{1 / 2}
$$

で与えられる。ここで, $d$ は探針一試料間最近接距離を 表す。この方法では, 静電気力を非共振周波数での応答 として捉えるため, 高感度の静電気力計測は困難な場合 が多い注5。

これに対して静電気力の FM 検出では, 電場変調周波

注5 変調周波数をカンチレバーの第 2 共振周波数に合わせる ことで, 静電気力検出の高感度化また高速化を図る方法も ある15)。 




Fig. 4. Schematic of FM-KFM.

数を FM 検出帯域内に設定することで, FM 検出により 形状信号と静電気力が, 基本共振周波数で振動するカン チレバーの応答から同時に検出される14)。Fig. 4 に FM 検出方式の KFM の装置構成の模式図を示す。この方法 においては, 変調周波数そのものは非共振周波数であっ ても, 共振周波数の FM 変調成分として検出されること になる。周波数のシフト量 $\Delta f$ は, 次式のように変調周 波数ではなく, 静電気力の大きさを反映することになる。

$$
\Delta f=-\left(\frac{\pi \varepsilon_{0} R f_{0}}{\sqrt{2} k A^{3 / 2} d^{1 / 2}}\right)\left(V_{D C}+V_{S}\right) V_{A C} \cos \omega_{m} t
$$

したがって, FM 検出法においては, 非共振角周波数 $\omega_{m}$ $(\sim 2 \pi B)$ における変調であっても, 検出信号は共振周 波数 $f_{0}$ の変調として捉えられるために $f_{0} / B$ 程度の感度 利得があり, 電位分解能の点で有利となる。実際, FM 検出法における最小検出電圧は,

$$
\Delta V_{\min }-\mathrm{FM}=\frac{k A^{1 / 2} d^{1 / 2}}{\sqrt{3} \pi \varepsilon_{0} R f_{0} V_{\mathrm{AC}}} n_{\mathrm{det}} B^{2 / 3}
$$

で与えられ， $\Delta V_{\min -\mathrm{AM}}$ のと比較すると,

$$
\frac{\Delta V_{\min }-\mathrm{AM}}{\Delta V_{\min }-\mathrm{FM}}=\sqrt{\frac{3}{8}} \frac{f_{0}}{B}
$$

となり, 典型的な条件として, $f_{0}=300 \mathrm{kHz}, B=1 \mathrm{kHz}$ とすると, FM-KFM の感度利得は約 180 倍となる。

\section{3. 有機分子の表面電位測定の現状}

\section{1 アルカンチオール薄膜の表面電位計測}

基板上に有機分子薄膜がある場合は，(1）分子-基板
界面での電荷移動に起因する界面分極，あるいは，(2) 分子のもつ電気双極子モーメントによる分極からの寄与 が上記電気 2 重層に加わるため, 分子基板界面の分極を 直接測定することが可能となる。ここでは，（2）の例と して, 鎖長の異なるメチル基終端アルカンチオール $\left(\mathrm{CH}_{3}\right.$ $\left(\mathrm{CH}_{2}\right)_{\mathrm{n}-1-\mathrm{SH}}$ : 以下 $\mathrm{C}_{\mathrm{n}}$ と記載）からなる相分離系の自己 組織化単分子（SAM: Self-assembled monolayers）膜の表 面電位測定を行うことで, その鎖長依存性を測定した最 近の実験結果について述べる16)。

アルカンチオール SAM 膜の表面電位の鎖長依存性に ついては, Evans らの報告がある17)。彼らはケルビンプ ローブ法（古典的振動容量法）を用いて巨視的な表面電 位測定を行い，その表面電位が鎖長に対して線形に上昇 する $\left(\mathrm{CH}_{2}\right.$ 当たり約 $\left.9.3 \mathrm{mV}\right)$ と報告した。その後, Lü らは, マイクロコンタクトプリンティングによってパタ 一ニングした試料を用いて大気中の KFM 観察を行い, $\mathrm{CH}_{2}$ 当たり約 $14 \mathrm{mV}$ 上昇することを報告した ${ }^{18)}$ 。ケル ビン法および KFM において，その表面電位はプローブ に対する接触電位差という形で検出される。しかしなが ら, プローブの絶対電位は測定環境に応じて, 分子吸着 などにより容易に変化する可能性があることから, Lü らの実験のように, 2 種類の分子の相対的な表面電位差 を検出するほうが望ましい。これらの実験では, 室温真 空蒸着によって作製された金薄膜基板上の SAM 膜を試 料として用いており，基板は単結晶基板ではなかった。 この場合, 金基板の平坦性は悪く, 分子の配向性につい ても疑問が残る。そこで, われわれは, 2 種の分子を相 分離させることにより $\mathrm{Au}(111)$ 面上に 2 種のナノスケ 
ールドメインを作製し，これらのドメイン間の表面電位 を比較することで分子の電気双極子を評価した ${ }^{16)}$ 。

Fig. 5 (a) - (d) に $\mathrm{C}_{12} / \mathrm{C}_{8}$ 相分離 SAM 膜の FM-AFM/ KFM による超高真空中での観察結果を示す。（a）は表 面形状像，（b）は表面電位像，(c) はそのモデル図およ び（d）は表面電位ラインプロファイルである。表面形 状像より SAM 膜は明らかに相分離していることがわか る (明部： $\mathrm{C}_{12}$, 暗部 $: \mathrm{C}_{8}$ )。さらに, 表面電位像では鎖 長の長い分子の方が, 表面電位が高いことを示しており, その電位差は $40 \mathrm{mV}$ である。同様に, $\mathrm{C}_{10}, \mathrm{C}_{14}$ を含む 相分離 SAM 膜を作製し，表面電位の鎖長依存性を調べ た。その結果を Fig. 6 に示す。表面電位は鎖長に対して ほぼ線形に増加し，その傾きは $\left(\mathrm{CH}_{2}\right)$ ユニット 1 つあ

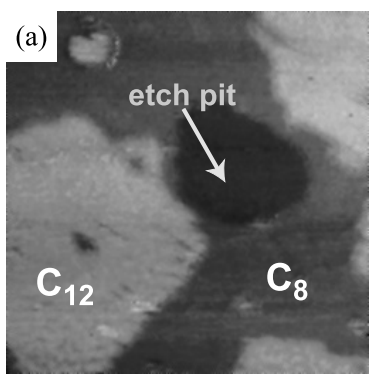

(c)

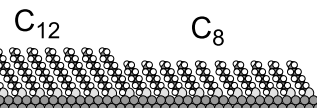

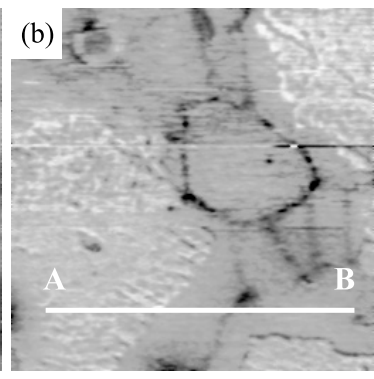

(d)

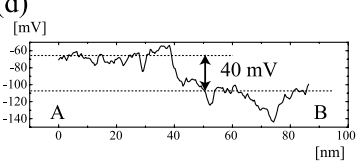

Fig. 5. (a) NC-AFM image of a $\mathrm{C}_{8} / \mathrm{C}_{12}$ PS-SAMs (100 nm $\times 100 \mathrm{~nm}, \Delta f=-120 \mathrm{~Hz}$, Pt-Ir coated cantilever). (b) Surface potential image simultaneously obtained with (a). (c) Schematic illustration of possible structure models of the $\mathrm{C}_{8} / \mathrm{C}_{12}$ PS-SAMs. (d) Crosssectional surface potential plots taken on the line $A B$ in (b).

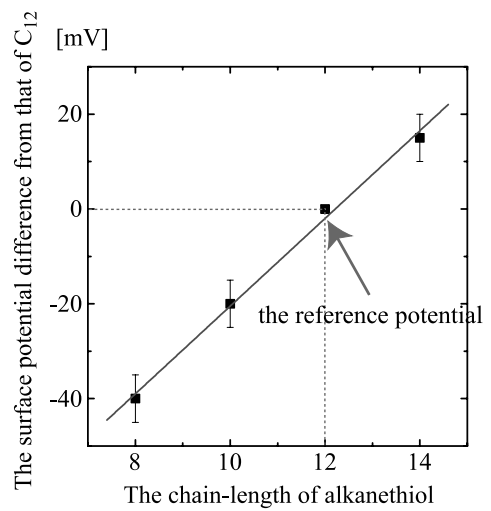

Fig. 6. Plots of the relative surface potential against the potential of $\mathrm{C}_{12}$ domains as a function of the chain length. The error bars were estimated from the noise in the experiment.
たり約 $9 \mathrm{mV}$ であった。これは Evans らによるケルビン 法での測定結果にほぼ一致している。Lüらの実験値 (14 $\mathrm{mV})$ とはやや離れているが, 彼らの試料はマイクロコ ンタクトプリンティングによって作製された SAM 膜で あり, 結果のばらつきが大きいことが影響しているかも 知れない。

鎖長に対して表面電位が増加するのは，アルカンチオ ール分子のもつ電気双極子モーメント（金基板に対して 上向き）によると考えられている。このケースでは，鎖 長の増加は電気双極子の長さの増加に相当し, 結果とし て双極子による電位が上昇すると考えられる。

\section{2 poly-PTS 単結晶の高分解能 KFM 測定}

ポリジアセチレン結晶は, 代表的な 3 次非線形光学材 料として, 従来, 精力的に研究が進められて来たが, 光 誘起相転移などその特異な物性から近年注目を集めてお り, 分子スケールでの構造・物性評価は大変興味深い。 ここでは, 代表的なポリジアセチレン結晶である polymerized-hexadiyne-1,6bis (p-toluene-sulphonate) 単結晶 (poly-PTS 単結晶) の超高真空中における FM-AFM 評 価について述べる19)。

poly-PTS 単結晶はPTS モノマー単結晶に $\gamma$ 線を照射 し, 固相重合させることよって作製された。結晶は, 単 斜晶（空間群 $\mathrm{P} 21 / \mathrm{c}$ ）に属し, 格子定数は $a=1.449 \mathrm{~nm}$, $b=0.491 \mathrm{~nm}, c=1.494 \mathrm{~nm}, \beta=118.1^{\circ}$ である20)。

Fig. 7 (a) に, poly-PTS 単結晶 $b c$ 䢃開面の周波数シ

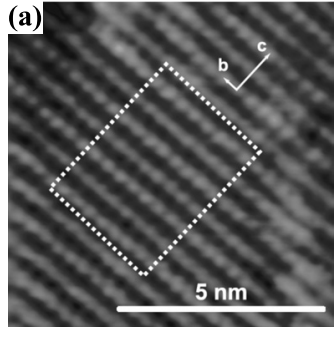

(c)

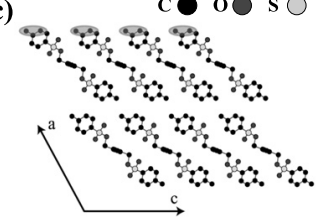

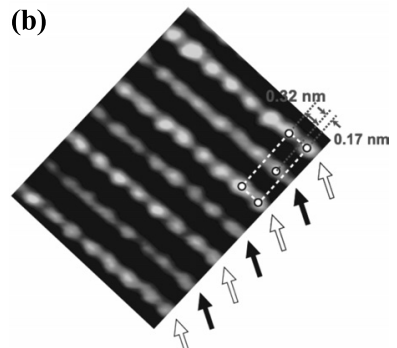

(d)

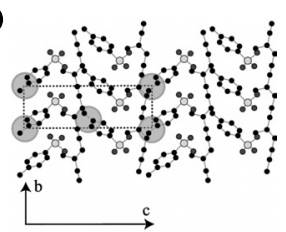

Fig. 7. Frequency image of poly PTS single crystals obtained by constant height mode NC-AFM $(10 \mathrm{~nm} \times$ $10 \mathrm{~nm}$, averaged frequency shift $=-80 \mathrm{~Hz}$, highlydoped n-Si cantilever). (b) High-contrast and enlarged frequency shift image of the area enclosed by dotted rectangle in (a). (c) The molecular structures of the $a c$-plane of bulk poly-PTS crystals. (d) The expected model structures of the NC-AFM image of a $b c$ cleaved surface of poly-PTS. 
フト像を示す(高さ一定モード)。b 軸方向に $0.75 \mathrm{~nm}(b / 2)$ 周期のストライプ構造が確認でき，さらに各ストライプ において $0.49 \mathrm{~nm}(c)$ 間隔の輝点を確認することができ る。Fig. 7(b) は, Fig. 7(a) 中の白点線で囲んだ部分を 拡大した図で, 図中の白点線の長方形は $b c$ 面のユニッ トセルに相当する。 $a c$ 面および $b c$ 面の結晶構造モデル 図を Fig. 7 (c)，（d)に示す。ジアセチレン主鎖の片方の PTS 側鎖は, 隣接したジアセチレン主鎖の下方に入りこ み, 片方の PTS 側鎖のみが表面に突き出している（(d) には表面に突き出す側鎖のみを図示)。これより, AFM 像における輝点は, PTS 側鎖先端部のメチル基とベンゼ ン環の一部分 (Fig. 7 (c), (d) 中の楕円部) に相当すると 考えられる。また，（b）中の b 軸方向に延びるストライ プ構造は, 白矢印で示したやや明るい列と黒矢印で示し た暗い列とで構成されていることがわかる。詳細は, 今 後の研究を必要とするが, 表面緩和の影響が考えられる。

Fig. 8 に, 同時に得られた, 表面形状像 (a), エネル ギー散逸像（b), 表面電位像（c）を示す。Fig. 7 と同 様に, 平行に延びる PTS 側鎖列が, 中心部の結晶欠陥 部（円で囲まれた領域）とともに確認できる。

Fig. 8 (c) の表面電位像においても, 分子スケールの コントラストが得られていることが確認できる。ポリジ アセチレンは一般にドーピングによりジアセチレン主鎖 方向に高い導電率を有するようになることが知られてい るが, 本研究で用いた poly-PTS はドープされていない ことから, その解釈は容易ではない。コントラスト成因 の 1 つには, poly-PTS 上の局所電荷分布がありうる。 そこで, PTS モノマーおよびダイマーについて, Mulliken 電荷の計算を行った。構造最適化は Gaussian 03 プログ
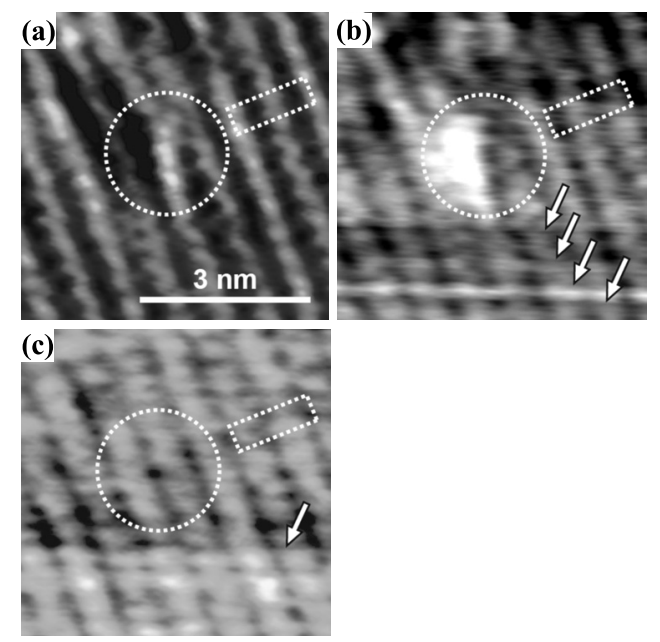

Fig. 8. Constant frequency shift mode NC-AFM images of a poly-PTS single crystal $(6 \mathrm{~nm} \times 6 \mathrm{~nm}, \Delta f=-100$ Hz). (a) Topography. (b) Energy dissipation. (c) Surface potential.
ラムを用いた密度汎関数法によって行った ${ }^{21)}$ 。基底関数 は 6-31G(d,p) を採用した。その計算結果をそれぞれ Fig.9 (a), (b) に示す。この結果に示されるように, PTS モノマー, ダイマーいずれにおいても, $\mathrm{S}$ 原子およびそ の周辺の 3 つの $\mathrm{O}$ 原子における電荷はそれぞれ約+ $1.22,-0.53,-0.48,-0.52$ となっており，この值は 他のほとんどの原子の電荷量に比べて 10 倍以上も大き い。つまり, PTS モノマーおよびダイマー上では, 電荷 のほとんどは $\mathrm{SO}_{3}$ 近傍に局在し, ジアセチレン主鎖お よびベンゼン環上にはほとんど有効電荷が存在しないこ とがわかる。また, モノマーとダイマー間で, 計算結果 にはほとんど差がないことから, 重合に伴う電子状態の 変化はほとんどないと考えられ, poly-PTSにおいても 同様の電荷の偏りが存在していると考えることができ る。このような電荷の偏りが, 分子スケール表面電位コ ントラストの起源となった可能性がある。

興味深いことに, Fig. 8（a）の表面形状像で確認され る結晶欠陥近傍においては, 表面電位コントラストには ほとんど影響がなく, b 軸方向のストライプ状の電位コ ントラストが明瞭に確認できる。この場合の表面電位像 は, 深さ方向にある程度平均化された電気的情報を検出
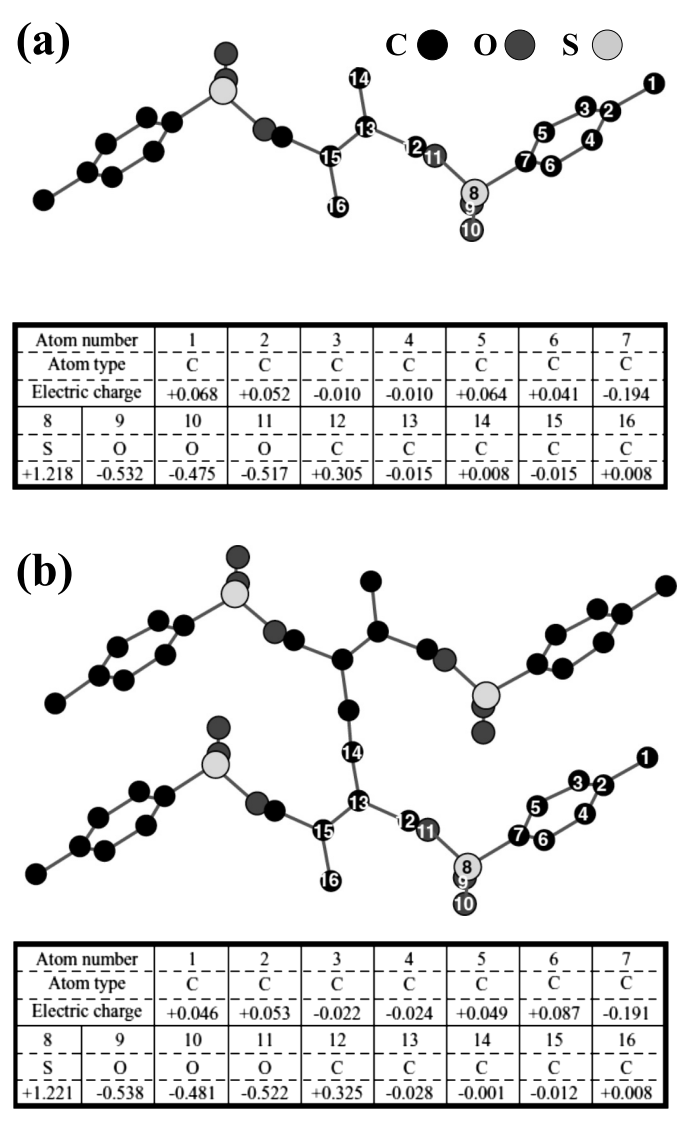

Fig. 9. Mulliken atomic charges on $\mathrm{C}, \mathrm{S}$ and $\mathrm{O}$ calculated at the B3LYP/6-31G $(d, p)$ level. 
している可能性がある。

\section{4. カーボンナノチューブ電界効果トランジ スタの電位評価}

単層カーボンナノチューブ（SWNT）は理想的な一次 元特性を有し, バリスティック伝導や単一電子トンネル などの特異な物性を示すことから，基礎・応用の両面か ら精力的に研究が進められている。特に, SWNTをゲ ートチャネルに用いたカーボンナノチューブ電界効果卜 ランジスタ（CN-FET）は次世代のナノスケールのデバ イスとして期待されている。その特性はSWNT と金属 電極との界面の電子状態によって支配されると考えられ ており22 25), 接合界面およびSWNT の電子状態を解析 することは本質的に重要となる。SWNT の電子状態の 直接計測法としては, 走查トンネル顕微鏡・スペクトロ スコピー $(\mathrm{STM} ・ \mathrm{STS})$ が用いられてきた。しかしなが ら，STMでは絶縁体上に配置されたデバイス構造の SWNT を測定することは, その原理上困難であり, 電 極間に溝（トレンチ構造）を作製しその間に橋渡しした SWNT の測定という特殊な報告例しかない。一方，KFM は, 動作状態の CN-FET の電子状態を評価できる方法と して大きく期待されている26)。ここでは, CN-FET のド レインあるいはゲートバイアスを加えた状態における SWNT チャネルの FM-KFM 電位計測の実験について紹 介する27)。本測定では，探針を SWNT チャネルのある 局所領域に位置決めすることが必須となるが，こうした 精密な位置決めは超高真空装置内では困難なため, 測定 は, 制御系を改造した市販の簡易真空型の AFM 装置(日 本電子製 JSPM-4200）を用いて, 約 $1 \times 10^{-3} \mathrm{~Pa}$ の真空環 境で行った。FM 検出器としては, 前項と同様, KI-2001 XEL（京都インスツルメンツ製）を用いた。

CN-FET の構造模式図を Fig. 10 (a) に示す。ソース およびドレインとなる 2 つ金属電極が $\mathrm{SiO}_{2}$ 膜 $(300 \mathrm{~nm}$ 厚） $/ \mathrm{Si}$ 基板上に作製され，両電極はゲートチャネルと してはたらくSWNTによって接続されている。 $\mathrm{Si}$ 基板 $(\mathrm{p}+)$ はバックゲートとして使用される。金属電極には, $\mathrm{Au}$ あるいは Ti を使用した。SWNT の両電極間への接続 には誘電泳動法を用いた ${ }^{28)}$ 。誘電泳動法は, 元々溶液中 のコロイドや細胞などの粒子を捕集する方法として用い られていた手法である。対象分子に外部より交流電場を 加えると誘起双極子が生じ，この誘起双極子が外部電場 と結合して駆動力となることを利用して, 対象分子を駆 動する。実際の誘起双極子の大きさは, 対象分子単体で 決まるのではなく, それを取り囲む溶媒の誘電率の差に 依存するため, 適切な溶媒の選択が必要となる。また, 駆動力は電場勾配の大きさに依存するため, 試料は電界 (a)

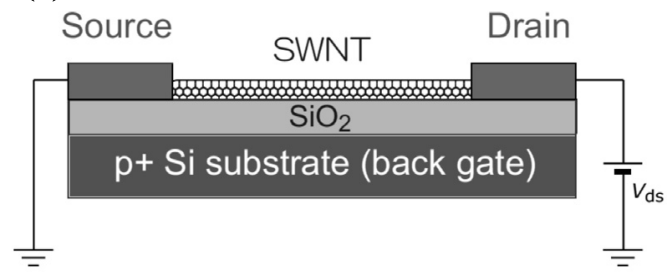

(b)



Fig. 10. (a) Structure of a CN-FET. (b) Deposition of SWNTs between the two electrodes using dielectrophoresis method.

が集中する領域に向けて駆動されることになる。

われわれは，Fig. 10（b）に示すように，エタノール に分散させた SWNT（Bucky USA 社製）溶液を $1 \mu l$ 滴 下し，溶液が乾燥するまで，電極間に $1 \mathrm{MHz}, 2 \mathrm{Vp}-\mathrm{p}$ の交流電圧を印加し続けた。分散溶液の濃度は, SWNT を限外濾過精製した上澄み液であるため正確にはわから ないが，およそ $1 \mathrm{ng} / \mu l$ 程度であると推定される。

Fig. 11 （a）に，Ti 電極間に SWNT を架橋して作製さ れた CN-FET の 1 例（AFM 像）を示す。SWNT 部の高 さは $4 \mathrm{~nm}$ であることから, 数本の SWNT から構成され たバンドルが架橋していると考えられる。Fig. 11（b) はその電気特性で, ドレイン電流のゲート電圧依存性か ら FET 動作することが確認された。ゲート電圧依存特 性の測定結果から，ゲートバイアス電圧が $3 \mathrm{~V}$ 以下では $\mathrm{p}$ 型伝導することがわかった。一方， $3 \mathrm{~V}$ 以上ではドレ イン電流は再び大きくなることから，この領域では $\mathrm{n}$ 型 伝導特性をもつことが示された。つまり，この試料は両 極性特性をもっている。

この CN-FET 試料に対して, FM-KFM による表面電 位測定を行った。まず，ゲート電圧を加えない状態でド レイン電圧のみを変化させた場合，SWNT チャネル部 の電位はほぼ平坦で, 電位降下のほとんどは電極端で起 きることが確認された。次に，ドレイン電圧を一定に保 ち $\left(V_{d s}=1 \mathrm{~V}\right.$ ，および $\left.V_{d s}=3 \mathrm{~V}\right)$, ゲート電圧 $\mathrm{Vg}$ を+2 $\mathrm{V}$ から-2 V まで $1 \mathrm{~V}$ 刻及で変化させて, FM-KFMによ り表面電位観察を行った。その結果を Fig. 12 に示す $\left(V_{d s}=1 \mathrm{~V}\right.$ の場合)。また，これらの表面電位像から求 められた, SWNT に沿っての電位変化（電位プロファ 
(a)

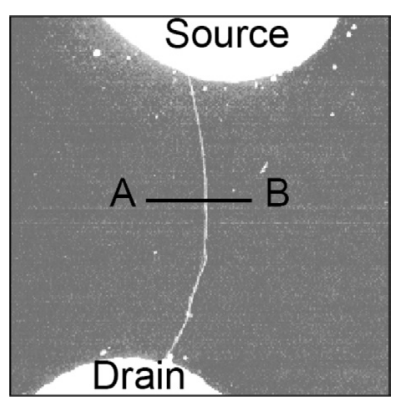

(b)

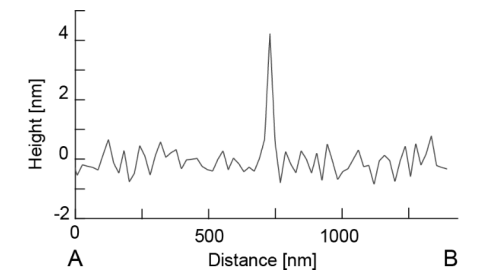

(c)

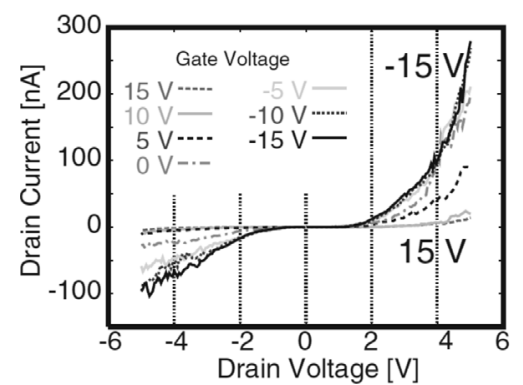

Fig. 11. (a) Topographic image of SWNTs connected to both Ti electrodes with a gap distance of about 4 $\mu \mathrm{m}(5 \mu \mathrm{m} \times 5 \mu \mathrm{m}$, Pt-coated cantilever $)$. A single bundle of SWNTs extending between the electrodes can be seen. (b) Drain current vs. drain voltage characteristics of this sample. The gate voltage was changed from $-15 \mathrm{~V}$ to $15 \mathrm{~V}$ in $5 \mathrm{~V}$ steps.

イル）をFig. 13 に示す。Fig. 13(a), (b)は, 各々 $V_{d s}=1$ $\mathrm{V}, V_{d s}=3 \mathrm{~V}$ の場合の電位プロファイルに対応する。 $\mathrm{Ti}$ 電極では, ドレイン電極端で, ゲート電圧に依存する顕 著な電位変化が生じることがわかる。

SWNT の仕事関数は $4.8 \mathrm{eV}$ だと報告されており ${ }^{29)}$, Ti の仕事関数 $4.3 \mathrm{eV}$ より大きいために, $\mathrm{p}$ 型領域でキャリ アとなるホールに対して, Schottky 障壁が形成されてい ると考えられる。KFMにより測定された, チャネルに 沿っての表面電位は, チャネル上のバンドの傾き/曲が りを反映するから, 電位プロファイルから SWNT のバ ンド構造を推察することが可能となる。ドレイン端にお ける表面電位の大きなゲート電圧依存特性は, SWNT の電子状態が大きくゲート電圧に依存して変化すること を示している。実際, この CN-FET のドレイン電流-ゲ 一ト電圧特性は, ゲート電圧がー $2 \mathrm{~V}$ から+2 V の領域 で, 空乏領域特性を示し大きくドレイン電流は変化する。 これらの結果を説明しうるバンド構造モデルを Fig. 14 (a) $V \mathrm{~g}=2 \mathrm{~V}$

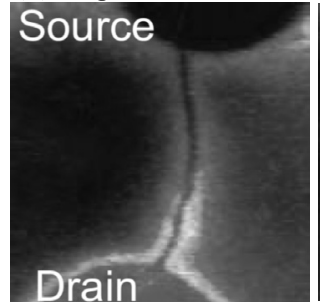

(b) $V \mathrm{~g}=1 \mathrm{~V}$

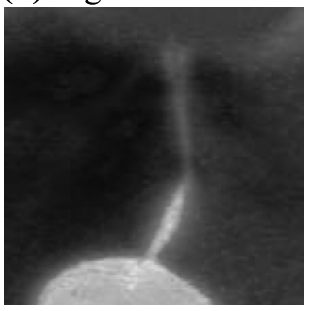

(c) $V \mathrm{~g}=-1 \mathrm{~V}$

(d) $V g=-2 \mathrm{~V}$
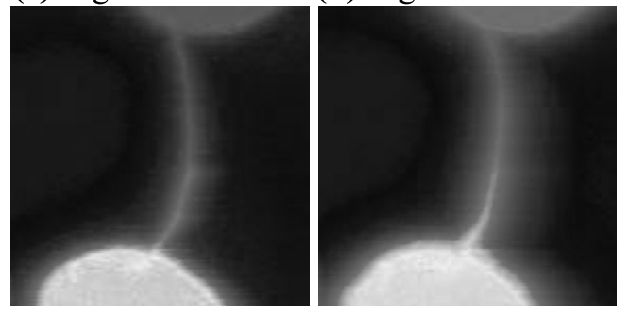

Fig. 12. Surface potential images of the CN-FET sample shown in Fig. 11, each obtained at a gate voltage of $2 \mathrm{~V}(\mathrm{a}), 1 \mathrm{~V}(\mathrm{~b}),-1 \mathrm{~V}$ (c) and $-2 \mathrm{~V}(\mathrm{~d})$, respectively, while the drain voltage was fixed at $1 \mathrm{~V}$. Although the potential brightness for each image was adjusted to enhance the contrast, the source potential was always grounded.

(a)

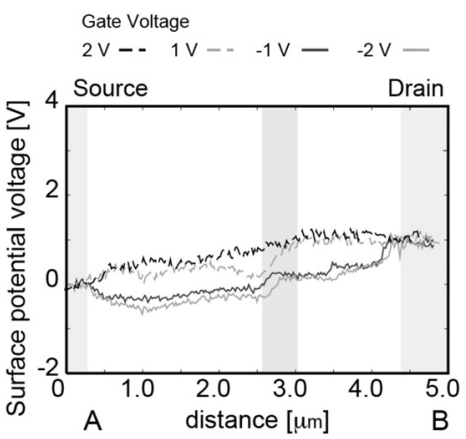

(b)

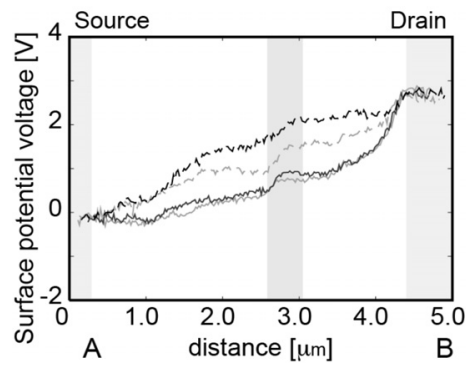

(c)

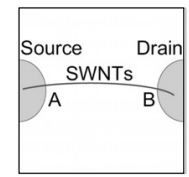

Fig. 13. Surface potential profiles along the bundle of SWNTs from the Ti source to the Ti drain for various gate voltages ranging from -2 to $2 \mathrm{~V}$ at a fixed drain voltage. The dark shaded areas correspond to the electrodes. (a) $V_{d s}=1 \mathrm{~V}$. (b) $V_{d s}=3 \mathrm{~V}$. 
(a) Gate bias +

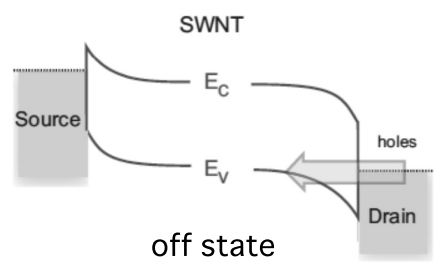

(b) Gate bias -

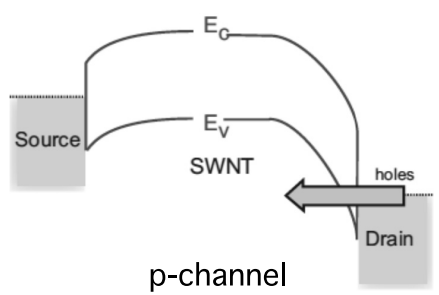

Fig. 14. Band diagrams of SWNTs connected with the Ti drain and source electrodes in the off state (a) and in the on state (hole conduction) (b).

(a)，（b)に示す。ゲート電圧に依存して，バンド構造は Fig. 14(a) から（b）のように変化し，ドレイン端での Schottky 障壁における障壁厚さは変化すると思われる。

つまり，ドレイン電極端から SWNT にトンネル注入さ れるホールのトンネル確率が，ゲート電圧により変調を 受けることで，電流変化が生じると考えられ，いわゆる 「Schottky 障壁変調モデル」を支持する。

Fig. 13 の電位プロファイルには, SWNT の途中（Fig. 13 でプロファイル中央部のグレー領域）に電位変化が みられる。この電位変化が起きている部分と考えられる 範囲の AFM 像を拡大してみると, Fig. 15 のように SWNT が途中で分岐していることがわかり，陷領域 に対応していることが判明した。ただし，先に述べたよ うに, ゲート電圧を加えない状態での表面電位は, SWNT 上で一様に平坦であったことを考虑すると，ゲート電圧 を加えたことで $\mathrm{SWNT}$ 周囲の $\mathrm{SiO}_{2}$ 上へと拡散・束縛さ れた電荷が，SWNT チャネルへの伝導に影響したもの と思われる。より精密な議論のためには, SWNT の周 辺電荷の影響を低減することが必要となる。

\section{5. 課 題と 展 望}

走査プローブ顕微鏡は，極限までに先鋭化した探針と 対象試料との相互作用を頼りに, 原子・分子スケールで の表面情報を捉えようとする装置である。相互作用の定 量化を目指そうとするとき，この「極限までに先鋭化し た探針」という部分が曲者である。先鋭でかつ完全に定 量化された（規整された）探針を得るのは非常に困難な

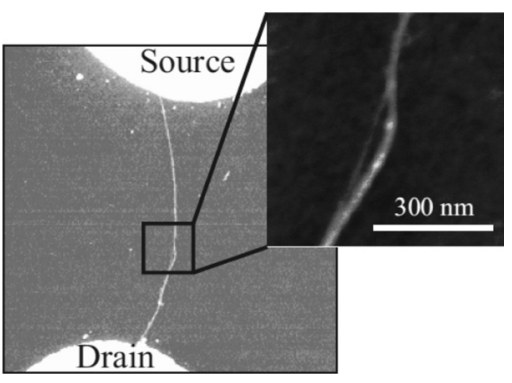

Fig. 15. The topographic image at a position where the potential was sharply changed (light shaded region in Fig. 13) is magnified. The SWNT bundle was untwisted around this point.

ことから, プローブ顕微鏡は分解能と定量性の問題を, 常に二律背反的に抱えることになる。ケルビンプローブ 原子間力顕微鏡は，零位法による電位測定を取り入れる ことによって，こうしたプローブ顕微鏡の中にあって， 珍しく（?）定量的な手法と見なされている。しかしな がら, 応用が進むにつれて, 種々の課題も浮かび上がっ ている。以下に，非常に雑感的ではあるが，これらの課 題と展望について述べたい。

元々, KFM における接触電位差を打ち消す測定法と いうアイデアは，インピーダンスが十分低い，一様な 2 導体系の測定を前提としている。したがって, 電位の異 なる複数の電極や絶縁体が測定対象と混在する場合は, そもそもこの前提から大きく外れており, 得られた測定 值は精査に吟味する必要がある。特に，2つの物質の境 界部など背景電場が大きく変化する領域では，探針自身 の形状も問題となる。探針・試料の形状効果を含めた電 場計算を行い，測定された電位の意味を議論する必要が ある。一方，絶縁体が含まれる場合は，さらに「厄介な」 問題となるが，同時に基礎・応用の両面で大変興味深い 問題である。本稿では，議論する紙数はなかったが，最 近，さまざまな実験結果も報告されており ${ }^{30)}$ ，今後の進 展に注目したい。

本稿でも紹介したように, FM-KFMによって, 原子・ 分子スケールでの表面電位コントラストが得られること が報告されている19,31)。その起源としては, 局在電荷 や分子双極子による静電気的コントラストが指摘されて いる。分子の双曲子モーメントや原子レベルの局在電荷 が 1 つ 1 つ見えることは, まことに驚異的ではあるが, 静電的相互作用は近距離力ではないことから, 純粋に静 電気的相互作用によって, 原子・分子コントラストが得 られるかは議論の別れるところである。一方で，原子ス ケールのバイアス分光法の結果も報告されており ${ }^{32)}$ ，量 子効果を含めた厳密な計算との定量的な対応が強く望ま れている。 
$\mathrm{KFM}$ ・AFM では，相互作用力をカンチレバーのたわ みによって検出するために, 高感度の変位測定系をもつ 必要がある。通常, この変位測定には光てこ法や光干渉 法などの光変位測定系が使用されるが, 照射光は全てカ ンチレバー背面で反射される訳ではなく, 試料表面にも 少なからず光が照射されることになる。このため, 光敏 感な材料を測定するときは注意が必要となる。近年, MEMS 技術の進展に伴い, 変位センサーを内蔵する自 己検出カンチレバーが実用化されており, 光を使用しな い $\mathrm{KFM}$ ・AFM も可能である33)。現状では, これら自己 検出カンチレバーの変位感度は光変位測定系に比べると まだかなり低いため, 分解能・力検出感度を必要とする 応用には向いていない。感度向上に向けての今後の開発 に期待したい。

こうして, 現状での課題を列挙してみると，それぞれ の課題は非常に興味深い話題となっていることにあらた めて気付く。KFM は, 強力なナノスケール電気解析手 法として定着している一方で, 依然ミステリアスな側面 を少なからずもっており, 筆者には大変魅力的な存在に 思われる。

\section{謝 辞}

本稿で紹介した研究の一部は, 科学技術振興機構・戦 略的創造研究推進事業 (CREST) および文部科学省「ナ ノ計測・加工技術の実用化開発」事業（リーディングプ ロジェクト）の下に遂行された。また，本稿を執筆する にあたって, 資料の作製にご協力いただいた京都大学工 学研究科 - 佐藤宣夫氏, 同 - 一井崇氏, 同 - 宮戸祐治氏 に感謝致します。

\section{文献}

1) Lord Kelvin: Philos. Mag. 46 (82), (1898).

2) M. Nonnenmacher, M.P.O' Boyle and H.K. Wickramasinghe: Appl. Phys. Lett. 58, 2921 (1991).

3) F.J. Giessibl: Science 267, 68 (1995).

4) H. Yamada: "Non-Contact Atomic Force Microscopy", ed. by S. Morita and R. Wiesendanger (Springer, 2002) pp.193-212.

5) 山田啓文 : 表面科学 23, 36 (2002).

6) Q. Zhong, D. Inniss, K. Kjoller and V.B. Elings: Surf. Sci. 290, L 688 (1993).

7) T.R. Albrecht, P. Grütter, D. Horne and D. Ruger: J. Appl. Phys. 69, 668 (1991).

8) F.J. Giessibl: Phys. Rev. B 56, 16010 (1997).

9) R. García and Á. San Paulo: Phys. Rev. B 60, 4961 (1999).
10) K. Kobayashi, H. Yamada, H. Itoh, T. Horiuchi and K. Matsushige: Rev. Sci. Instrum. 72, 4383 (2001).

11) T. Fukuma, K. Kobayashi, H. Yamada and K. Matsushige: J. Appl. Phys. 95, 1222 (2004).

12) A. Kühle, A. Sфrensen and J. Bohr: J. Appl. Phys. 81, 6562 (1997).

13) L. Olsson, N. Lin, V. Yakimov and R. Eriandsson: J. Appl. Phys. 84, 4060 (1998).

14) S. Kitamura and M. Iwatsuki: Appl. Phys. Lett. 72, 3154 (1998)

15) A. Kikukawa, S. Hosaka and R. Imura: Appl. Phys. Lett. 66, 3510 (1995).

16) T. Ichii, T. Fukuma, K. Kobayashi, H. Yamada and K. Matsushige: Nanotechnology 15, S30 (2004).

17) S.D. Evans and A. Ulman: Chem. Phys. Lett. 170, 462 (1990)

18) J. Lü, E. Delamarche, L. Eng, R. Bennewitz, E. Meyer and H.-J Güntherodt: Langmuir 158, 184 (1999).

19) T. Ichii, H. Kawabata, T. Fukuma, K. Kobayashi, H. Yamada and K. Matsushige: Nanotechnology 16, S22 (2005).

20) D. Kobelt and E.F. Paulus: Acta. Cryst., Sec. B 30, 232 (1974).

21) M.J. Frisch et al.: Ab-initio MO Program Gaussian 03, Revision B.04 (Gaussian, Inc., Pittsburgh, PA, 2003).

22) S. Heinze, J. Tersoff, R. Martel, V. Derycke, J. Appenzeller and Ph. Avouris: Phys. Rev. Lett. 89, 106801 (2002).

23) J. Appenzeller, J. Knoch, V. Derycke, R. Martel, S. Wind and Ph. Avouris: Phys. Rev. Lett. 89, 126801 (2002).

24) M. RadosavljevicÅL, S. Heinze, J. Tersoff and Ph. Avouris: Appl. Phys. Lett. 83, 2435 (2003).

25) A. Javey, J. Guo, Q. Wang, M. Lundstrom and H. Dai: Nature 424, 654 (2003).

26) B.J. LeRoy, S.G. Lemay, J. Kong and C. Dekker: Appl. Phys. Lett. 84, 4280 (2004).

27) Y. Miyato, K. Kobayashi, K. Matsushige and H. Yamada: Jpn. J. Appl. Phys. 44, 1633 (2005).

28) X.Q. Chen, T. Saito, H. Yamada and K. Matsushige: Appl. Phys. Lett. 78, 3714 (2001).

29) S. Suzuki, C. Bower, Y. Watanabe and O. Zhou: Appl. Phys. Lett. 76, 4007 (2000).

30) C. Barth and C.R. Henry: Nanotechnology 17, S155 (2006).

31) T. Eguchi, Y. Fujikawa, K. Akiyama, T. An, M. Ono, T. Hashimoto, Y. Morikawa, K. Terakura, T. Sakurai, M.G. Lagally and Y. Hasegawa: Phys. Rev. Lett. 93, 266102 (2004).

32) T. Arai and M. Tomitori: Phys. Rev. Lett. 93, 256101 (2004).

33) N. Satoh, K. Kobayashi, S. Watanabe, T. Fujii, T. Horiuchi, H. Yamada and K. Matsushige: Jpn. J. Appl. Phys. 43, 4651 (2004). 